\title{
About Rethinking
}

It has become trite to observe that, given globalization, transnationalism and postcolonialism, not to mention the Europeanization of laws, every law student and every lawyer is bound to encounter foreign law in the course of her or his professional life. Consider the following manifestations of this multi-faceted phenomenon. International organizations create common legal norms and standards whose effectiveness depends on local interpretations. ${ }^{1}$ Increasingly, law-makers show themselves open to the influence of foreign legal ideas in the legislative process. ${ }^{2}$ Also, many appellate or supreme courts are prepared to refer to foreign law in their opinions. ${ }^{3}$ At least as importantly, perhaps, private parties often enter into legal arrangements, such as contracts or wills, featuring a foreign dimension. ${ }^{4}$ And it seems fair to assume, if in advance of empirical study, that while much doctrinal work remains disappointingly parochial, more and more scholarly writing purports to feature a cosmopolitan focus. In sum, nowadays, foreign law is everywhere and cannot be circumvented.

In line with these developments, the field commonly known as 'comparative law', which broadly speaking addresses engagement with foreign law and the comparison of laws, has significantly expanded over the past decades. The multiplication of journals, the proliferation of scholarship and the creation of courses or summer schools specifically devoted to comparative law are some indicators attesting to the increasing popularity of comparative legal studies. Within the Western legal tradition, the dominant position in comparative law has long been assumed by Konrad Zweigert and Hein Kötz, two leading German legal scholars. For more than four decades, Zweigert and Kötz's textbook, Introduction to Comparative Law, has governed much of the research undertaken in the field of comparative law and has defined, politically and otherwise, what kind of comparative legal research is to be regarded as 'good

\footnotetext{
1 See Anthea Roberts and others (eds), Comparative International Law (OUP 2018).

2 See Vito Breda (ed), Legal Transplants in East Asia and Oceania (CUP 2019).

3 See Mads Andenas and Duncan Fairgrieve (eds), Courts and Comparative Law (OUP 2015).

4 See James Gordley and Arthur T von Mehren, An Introduction to the Comparative Study of Private Law (CUP 2006).
} 
comparison'. ${ }^{5}$ Indeed, this 'seminal introduction to comparative law has been translated into many languages, enjoys enormous influence, and is familiar to practically every comparative lawyer in the world' ${ }^{6}$ Zweigert and Kötz's self-styled 'functionalist' method, grounded on a black-letter approach to law, has proved particularly authoritative. ${ }^{7}$ In recent years, however, some authors have mobilized cultural studies as well as economic, literary and philosophical ideas with a view to highlighting the shortcomings of orthodox comparative legal theory. ${ }^{8}$ Undoubtedly, the application of such perspectives offers fresh and crucial insights into the theory and practice of comparative law.

Problematically, though, even the most recent critical literature in the field still fails to address a certain number of key issues arising in comparative law. For example, the task of the comparatist is to explain, by making use of her or his language, a foreign law usually formulated in a different language. Specifically, the comparatist is frequently asked to translate various kinds of legal texts, such as treaties, statutes, judicial decisions, contracts and scholarship, from one language into another. Very often, the active or passive knowledge of a foreign legal language and culture is regarded as a sufficient condition for the translation of foreign legal materials. Indeed, while specialists in translation studies have long acknowledged that, properly speaking, translation is impossible or, at any rate, that translation effectively means transformation, the vast majority of comparatists either ignore or underestimate the obstacles standing in the way of every attempt at translation. In a context where the question of understanding proves of the utmost importance to lawyers working on the international scene the matter of the feasibility of translation needs to be probed, whether theoretically (can it be done?) or practically (how to do it?). Other illustrations of deficiencies abound (can the comparatist be objective? Must he or she be? Are some laws better than others, or is this a matter of preference? Are laws as similar as Zweigert and Kötz would have comparatists believe?).

In reaction to the state of play within the field as it currently stands, this co-authored book seeks to rethink comparative law by providing both students

5 Konrad Zweigert and Hein Kötz, Introduction to Comparative Law (Tony Weir tr, 3rd edn, OUP 1998).

6 Uwe Kischel, Comparative Law (Andrew Hammel tr, OUP 2019) 88.

See Ralf Michaels, 'The Functional Method of Comparative Law' in Mathias Reimann and Reinhard Zimmermann (eds), The Oxford Handbook of Comparative Law (2nd edn, OUP 2019) 345-89.

8 See David Nelken (ed), Comparing Legal Cultures (Dartmouth 1997); Pierre Legrand and Roderick Munday (eds), Comparative Legal Studies: Traditions and Transitions (CUP 2003); Pierre Legrand (ed), Comparer les droits, résolument (Presses Universitaires de France 2009); Teemu Ruskola, Legal Orientalism (Harvard University Press 2013); Mathias Siems, Comparative Law (2nd edn, CUP 2018). 
and their teachers with the intellectual equipment allowing them to approach foreign law in a meaningful way. ${ }^{9}$ Quite apart from addressing a range of topics that illustrate the contemporary relevance of comparative law, this book heightens sensitization to the singularity of foreign legal cultures and it invites familiarization with key aspects of the common law and civil law traditions which have defined a significant range of legal cultures worldwide over the past centuries. Operating from an interdisciplinary standpoint, these chapters also offer an introduction to philosophy, linguistics and translation studies with reference to legal interactions on the international scene. Throughout, the book uses concrete examples issuing from a number of different countries. These include illustrations drawn from Australian, Canadian, English, French, German and US law. At all times, the book prompts in-depth epistemological reflection upon the possibilities and limits of cross-border legal interaction. In this way, it aims to distinguish itself from the available literature in the field.

It remains to explain how we have understood co-authorship - indeed, how we have sought to rethink the idea of scholarly co-operation. First and foremost, we have been keen to avoid the usual model whereby the singular voices of the co-authors are effectively made to disappear, to invisibilize themselves, in favour of an unattributed and unattributable co-authorial speech ideally featuring no trace whatsoever that would allow the reader to identify the actual writer. Quite apart from striking us as unappealingly artificial, this approach, we thought, sits oddly with comparative law which, above all, extols pluralism. We have therefore organized the book so that each of the three co-authors is personally responsible for a third of the chapters, the different instalments accordingly appearing under individual signatures. The reader is therefore treated to three different comparative styles, emphases and tonalities; to three different expressions. Moreover, the chapters feature different substantive theoretical and practical orientations, not least as a result of the three co-authors' different personal and professional itineraries. Again, we simply could not bring ourselves to contrive the sort of spurious consensus that would have elided the fact of intellectual disparity or discrepancy, not to mention the counterpoints, arising as regards the various motifs under consideration - the very gist of scholarly conversation. Although the book is much the stronger for the diversity of approaches that we have sought to showcase, our preferred configuration entails that the finished product is not as silky or satiny as what readers may have come to expect from a co-authored text. We ask our read-

9 See also Günter Frankenberg, 'Critical Comparisons: Re-thinking Comparative Law' (1985) 26 Harvard International Law Journal 411; Günter Frankenberg, Comparative Law as Critique (Edward Elgar Publishing 2016). 
ership kindly to acknowledge the values that have informed our design and to accept the merits of our co-operative endeavour as we have framed it.

Rethinking Comparative Law is structured as follows.

Chapter 1, entitled 'The Epistemological Challenge: Does Law Exist?' (Geoffrey Samuel), might seem at first sight somewhat esoteric, even by critical comparative law standards. But consider the thesis that law is an entirely cultural phenomenon and the way this argument challenges the existence of what might be termed global or transnational law. Now, if such transnational law does not, or cannot, exist (save as a mass of meaningless words), as some comparatists claim, what are the implications for the existence of national law? And if national law exists, of what does it consist? Recent literature has begun to tackle these key epistemological questions, and it is the purpose of this chapter both to review such issues and to promote and defend fiction theory as an 'epistemological attitude', that is, as one possible response to the existence question. However, this approach could raise some awkward questions for comparatists.

Chapter 2, 'The Comparatist and the Illusion of Autonomy' (Simone Glanert), raises the following key questions: Is a comparatist ever free to think what she wants? Or is there something like a shared pool of information within which the comparatist dwells and which constrains her to discredit views and information inconsistent with her enculturation? Or is there an ability to resist the impulse to consonance and allow for the intrusion of foreign elements into one's inner world? How much adaptability can the comparatist legitimately apply in the formulation of her normative judgments? This argument claims that the relationship between self and world can be pertinently illuminated through a comparative jurisprudential investigation. Interestingly, John Rawls, in a fashion that can readily appear characteristic of US political philosophy, confers a central role to the idea of self-determination while Hans-Georg Gadamer highlights the idea of identitarian 'belongingness' in a manner that may seem typical of much post-Heideggerian continental philosophy. Purporting to eschew rules, circumvent functionalism, assert local knowledge and recognize contingent conceptions of justice, this chapter advocates an approach to the comparison of laws premised on a Gadamerian critical engagement with (legal) culture.

In Chapter 3, 'Methodology and Comparative Law: Programme Orientations', Geoffrey Samuel addresses method and methodology, an aspect of comparative law learning that has attracted much literature but also considerable controversy. There is thus talk of method being an epistemological obstacle and of methodological mishmashes. Part of the problem may lie with the discipline of law itself which has been governed by a paradigm - what might be called the authority paradigm - that has largely discouraged much serious investigation of methodological engagements. Of course, there are 
books on legal methods, but many are aimed at students beginning law degrees (although there are some notable exceptions). In a subject like sociology, by contrast, the literature indicates that methods are taken much more seriously because they are embedded in sociological theory. Theory and method are not to be seen as existing in separate domains. Comparative lawyers, who many argue need to be interdisciplinary in their approaches (although there are influential dissenters), find themselves caught in a no man's land between legal positivism and social and human sciences. Perhaps one problem attaches to the word 'method' itself, which, for one reason or another, has tended to acquire a rather shallow meaning in law. In this chapter, rather than focus on method, it was found to be more valuable to think in terms of comparative law research programmes or paradigms (using this latter term in a wider social-science sense). These various programmes are not meant to be understood as either exhaustive or exclusive; they are broad, often overlapping, currents or modes of engaging with a research object. The programmes are not theories as such, although they may be a means of engaging with theories if not developing new ones. They are, above all, frameworks (although not rigid ones) or, better still, orientations.

Chapter 4, 'Method as Deception' (Simone Glanert), critically assesses the recourse to method in comparative legal studies. It is hardly an exaggeration to think of method as a disciplinary hallmark. No discipline, it seems, can lay claim to intellectual respectability unless it features an accredited method. But comparative law is unusual inasmuch as it is commonly reduced to a method - and this by comparatists themselves. In other terms, comparative law would be a strictly methodological endeavour. Indeed, the leading textbook in the field describes comparative law as a 'heuristic method of legal science'. Yet, method remains woefully untheorized. Now, does it do more than betray 'science envy'? Can it effectively overcome situation (that of the law and that of the comparatist)? Is it in a position to offer epistemological guarantees of any kind? In sum, how, if at all, is method able to contribute to the credentialization of comparative law? Drawing principally on the work of Hans-Georg Gadamer, Jacques Derrida and Paul Feyerabend, this chapter aims to revisit the assumption of method as being the sine qua non for comparative inquiries in law.

In Chapter 5 on 'Comparisons Otherwise: The Merits of Interdisciplinarity', Alexandra Mercescu takes issue with the epistemic autarchy long entertained by mainstream comparative legal thought. The chapter argues that comparatists must not allow disciplinary monolinguism to prevail. In particular, it provides an explanation as to why comparatists should mobilize other disciplines in their research. In addition, since not all interdisciplinarities are equally promising from an epistemic point of view, the chapter seeks to establish what kind of interdisciplinary research comparatists should prefer. For this specific 
purpose, some of the philosophical and ideological assumptions underlying the different types of interdisciplinary constructions are examined.

Chapter 6 is dedicated to 'Comparing Comparisons' (Geoffrey Samuel). What is it to compare? How does one go about comparing? What are the problems and dangers inherent in such an exercise? These are just some of the general questions that comparatists must face. Not surprisingly, such issues raise complex epistemological and methodological matters. This is one reason why this chapter investigates comparison in some other disciplines in order to see if there are any lessons or insights across boundary lines for comparative lawyers. Or is it the case that each discipline, or certain groups of disciplines, presents its own epistemological framework so that any kind of meta-theory or meta-framework would be impossible?

Chapter 7, 'On the Untranslatability of Laws' (Simone Glanert), emphasizes the central role of language in comparative legal studies. The task of the comparatist being to explain foreign law, every comparative legal study implies acts of translation - and not only because foreign law is often formulated in a different language. Problematically, though, many comparatists appear unaware of the obstacles necessarily characterizing every attempt at translation. This chapter considers the extent to which legal translation can be regarded as being at all possible and investigates how to transpose foreign law across languages in a way that can do it justice. The text introduces various theories from the field of translation studies, outlining the different approaches that can be adopted by the legal translator, bearing in mind that the choice of one or another translation strategy is not innocent. The fact that there are potentially as many outcomes as there are theoretical frameworks on offer demonstrates, crucially, that no translation can ever escape its specific configuration in order legitimately to be considered true.

Chapter 8 addresses the matter of understanding through recourse to a case study. It is entitled 'The Corrida, For Example: How Comparative Understanding Fares' (Simone Glanert). First and foremost, comparatists have been expected to understand the foreign law under their scrutiny. Moreover, comparatists have been deemed able to achieve interpretive exactness and objectivity. Operating under 'scientific' cover, the habitual position holds that the deployment of the right methodological accoutrements permits a smooth appreciation of foreignness across laws, languages and cultures. Most problematically from the standpoint of comparative analysis, such assumptions however fail to do justice to the intricacies of intercultural dynamics. Contrary to the received view, intercultural interventions do not feature seamlessness but interruption and discontinuity, difference and misunderstanding. This chapter tracks an example illustrating these contentions and draws conclusions reverberating far beyond the specifics at hand. 
In Chapter 9, 'How Far Culture? A Critical Examination of Cultural Defence' (Alexandra Mercescu), it is argued that culture has been an incontrovertible presence in the treatment of such salient topics as legal transplants, comparative methodology, foreign law references or legal uniformization. Yet, the topic is far from being uncontroversial. Consider the debate surrounding the subject-matter of 'cultural defences', that is, instances where a litigant invokes cultural belongingness in order to escape or mitigate the predicament of the law. This chapter seeks to show how the often problematic manifestations of culture in the courtroom can inform a critical understanding of the theoretical notion of culture, which remains crucial for the comparatist taking the view that legal comparisons are ill at ease with positivistic and formalistic accounts of (foreign) law.

Chapter 10, entitled 'Comparison in Action: On the Beach' (Geoffrey Samuel), aims to move to a more practical level and to look at comparison in action. The theme of this practical exercise concerns the beach, which, at first sight, might seem a curious choice. But in fact, the beach has given rise to legal reflection in the civil and the common law traditions. Indeed, it has provoked factual analysis both in Roman law and in a relatively recent UK Supreme Court case, in turn inviting reflection about the methods of reasoning employed in deciding litigation problems, for example with respect to top-down versus bottom-up approaches, consequential reasoning, pluralistic methods and so on. There is equally a taxonomical dimension: are the laws governing beaches and any activities on them a matter of public or private interest?

Chapter 11, 'Quantifying Law? The Case of "Legal Origins"” (Alexandra Mercescu), argues that, out of the myriad encounters between law and economics, so-called Legal Origins theory is of particular interest to comparatists in that it purports objectively to measure and rank different national laws according to their economic performance. Highly influential given the support it found from the World Bank, the 'Legal Origins' literature has nonetheless been challenged on several grounds. This chapter analyses this theoretical model first and foremost epistemically, as a case of problematic interdisciplinary work. Specifically, it seeks to highlight the important limits of translating law into numbers and to make comparatists aware, in general, of the significant risks of letting one discipline dominate the other in the context of an interdisciplinary exchange.

Finally, Chapter 12 addresses the question 'Is There Generic Law? The Issue of Constitutionalism' (Alexandra Mercescu). The argument offers a critical examination of the concepts of generic law and, more specifically, of generic constitutional law. Often encountered in mainstream comparative law literature, the term 'generic' conveys the ideas that more and more states adopt similar constitutional provisions and that more and more judges employ similar tools of analysis to the point that one can document the emergence of 
a uniform body of constitutional theory, practice and doctrine that cannot be attributed to one particular jurisdiction only. Contrariwise, this contribution shows that generic law cannot exist since law's predisposition is to relocate itself in space and time. Armed with the willingness to undertake sufficient work, the comparatist will realize that differences pervade theory, practice and doctrine alike. Thus, she must be encouraged to put in place (in the place of orthodoxy's negation of place) a vision of law that makes room for place as constitutive of the legal.

Inevitably, the writing of this book made demands on people around us, whether in a personal or professional capacity. Simone Glanert, Alexandra Mercescu and Geoffrey Samuel are grateful to Pierre Legrand for his invaluable accompagnement. Also, Simone Glanert has been fortunate to count on Franz Werro's bracing encouragement. For her part, Alexandra Mercescu extends warm thanks to her family for their ever (re)invigorating support and to her friends at Nomos: Centre for International Research on Law, Culture and Power, who kindly read and discussed earlier versions of her contributions. And Geoffrey Samuel is indebted to Horatia Muir Watt. Collectively, we are obliged to Amber Watts at Edward Elgar Publishing for her outstanding co-operation throughout the publication process. We wish to express our sincere gratitude to Jordi Surroca, architectural photographer, for his generous permission to use his photography of the Convent de Sant Francesc for our book cover. We think it situates our project to excellent effect. 
Simone Glanert, Alexandra Mercescu, and Geoffrey Samuel - 9781786439475 Downloaded from PubFactory at 04/26/2023 11:11:19AM 